\title{
Rhodium-Catalyzed Ortho-Vinylation of 2-Arylpyridines and Its Application in the Total Synthesis of Palmatine
}

\author{
Shan Lv ${ }^{1} \quad$ Ruifang Nie ${ }^{1} \quad$ Lingmei Guo $^{1} \quad$ Yang Zheng $^{1} \quad$ Yanzhao Liu $^{1} \quad$ Li Guo $^{1} \quad$ Yong Wu${ }^{1}$ \\ 1 Sichuan Engineering Laboratory for Plant-Sourced Drug and \\ Research Center for Drug Industrial Technology, Key Laboratory of \\ Drug-Targeting and Drug Delivery System of the Education Ministry, \\ West China School of Pharmacy, Sichuan University, Chengdu, China \\ Pharmaceut Fronts 2020;2:e94-e99. \\ Address for correspondence Li Guo, PhD, West China School of \\ Pharmacy, Sichuan University, Chengdu 610041, China \\ (e-mail: guoli@scu.edu.cn). \\ Yong Wu, PhD, West China School of Pharmacy, Sichuan University, \\ Chengdu 610041, China (e-mail: wyong@scu.edu.cn).
}
Abstract
Keywords
- rhodium-catalyzed
- C-H activation
- ortho-vinylation
- potassium vinyltrifluoroborate
- palmatine

An efficient protocol by Rh-catalyzed direct $\mathrm{C}-\mathrm{H}$ vinylation of 2-arylpyridines with a commercially available and air-stable potassium vinyl donor has been developed. This method affords the corresponding pyridinyl styrene derivative with moderate to excellent yields under mild conditions, which is extremely beneficial to the total synthesis of the natural product palmatine.

\section{Introduction}

In the past few decades, transition metal catalyzed C-H bond functionalization has witnessed significant progress as it avoids tedious and costly preactivation of starting materials and minimizes the formation of byproducts. ${ }^{1-3}$ After decades of development, it has become a useful tool in the total synthesis of natural products. ${ }^{4-6} \mathrm{~A}$ lot of research studies have proved that transition metal catalyzed $\mathrm{C}-\mathrm{H}$ activation is a simpler and more time-saving methodology for the synthesis of natural products compared with traditional transformations. Here are just a few examples. Ellman's group ${ }^{7}$ synthesized the natural product pancratistatin through an amide-directed $\mathrm{C}-\mathrm{H}$ activation in 2017 (Scheme 1a), and Kazmaier's group ${ }^{8}$ completed the synthesis of cyclopeptide alkaloids abyssenine $\mathrm{A}$ and mucronine $\mathrm{E}$ by $\mathrm{C}-\mathrm{H}$ functionalization of $N$-methylated amino acids and peptides in 2018 (Scheme 1b). Meanwhile, our previous work ${ }^{9}$ successfully synthesized the natural compound decumbenine B via Ru (III)-catalyzed ortho-hydroxymethylation (Scheme 1c).

Palmatine, an isoquinoline alkaloid isolated from Fibraurea recisa Pierre (Chinese name: Huangteng), has a wide range of pharmacological and biological activities, such as antibacterial, antifungal, and antiviral effects. ${ }^{10,11}$ Clinically, palmatine has been used for the treatment of surgical infections, respira- tory and urinary tract infections, conjunctivitis, and gynecological inflammation. ${ }^{12}$ Due to the wide range of applications and exact efficacy in clinic, the demand for palmatine in the pharmaceutical market is growing. However, palmatine is in short supply because of the long growth cycle of the medicinal plant, or long synthetic route with low yield, environmentally unfriendliness, and high cost, etc. ${ }^{13,14}$ Therefore, developing a new and effective method to synthesize palmatine still has great practical significance. Based on structural analysis and our interest in $\mathrm{C}-\mathrm{H}$ functionalization, ${ }^{15-18}$ a retrosynthetic analysis route was proposed, as shown in Scheme 2. Through this route, palmatine could be synthesized in only four steps, and among this, the two-step $\mathrm{C}-\mathrm{H}$ activation reactions are crucial. Fortunately, our group has completed the synthesis of intermediate $\mathrm{B}$ by a water-mediated $\mathrm{C}-\mathrm{H}$ activation using primary amines and sulfoxonium ylides. ${ }^{19}$ Therefore, the ortho-vinylation of isoquinoline $B$ is our main research object.

As far as we know, there are no literatures on the direct $\mathrm{C}-\mathrm{H}$ vinylation of 3-arylisoquinolines. Based on the similarity of physical and chemical properties between 2-arylpyridines and 3 -arylisoquinolines, we decided to study the ortho-vinylation of 2-arylpyridines. Independent studies by the groups of Kakiuchi, ${ }^{20}$ Ellman, ${ }^{21} \mathrm{Mei},{ }^{22}$ and $\mathrm{Xu}^{23}$ reported that the direct $\mathrm{C}-\mathrm{H}$ vinylation of 2-arylpyridines could be accomplished with different vinyl sources catalyzed by ruthenium, or rhodium 
a) Ellman's work<smiles>CC1(C)O[C@H]2O[C@H](/C=C/[N+](=O)[O-])[C@H](OBr)[C@H]2O1</smiles><smiles>CC(C)(C)O[C@H]1C(C(C[N+](=O)[O-])c2cc3c(c(OCc4ccccc4)c2C(=O)N2CCCC2)OCO3)O[C@@H]2OC(C)(C)O[C@H]12</smiles><smiles>NC(=O)c1c([C@@H]2C[C@H](O)[C@@H](O)[C@H](O)[C@H]2O)cc2c(c1O)OCO2</smiles>

b) Kazmaier's work<smiles>[R]N(C)[C@H](C[2H])C(=O)Nc1cccc2cccnc12</smiles>

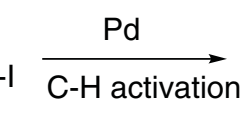<smiles>[R]N(C)[C@H](CBr)C(=O)Nc1cccc2cccnc12</smiles>

c) our previous work<smiles>COc1ccc(C=O)c(Br)c1O</smiles><smiles>CC(C)CO</smiles>

C-H activation<smiles>[R7]c1cc(OC)c2cc1/C=C\NC(=O)[C@H](CC(C)C#CC)NC(=O)[C@H]([C@@H](C)CC)NC(=O)[C@H](NC)C2</smiles>

$\mathrm{R}_{1}=\mathrm{H}$ abyssenine $\mathrm{A}$ $\mathrm{R}_{1}=$ OMe mucronoine $\mathrm{E}$

Scheme 1 Some examples of total synthesis of natural products by $\mathrm{C}-\mathrm{H}$ functionalization.

(Scheme 3a), but there remains some limitations, particularly with regard to high reaction temperature, toxic reactant, low yield, and using ligand additive. So it is of great value to explore a mild and efficient method to complete direct ortho-vinylation of 2-arylpyridines. Very recently, Zhou and coworkers reported an efficient $\mathrm{Rh}$-catalyzed direct $\mathrm{C} 2$-alkenylation of indoles, ${ }^{24}$ which is the first example for building a C2 block utilizing commercially available and air-stable potassium vinyltrifluoroborate as the vinyl source. We are interested in the practicability of this vinyl source in the $\mathrm{C}-\mathrm{H}$ bond functionalization and wonder if it can be used in 2-arylpyridines. Considering all the above facts, herein, we developed Rhcatalyzed direct $\mathrm{C}-\mathrm{H}$ vinylation of 2-arylpyridines with potassium vinyltrifluoroborate as the vinyl source under mild conditions (Scheme 3b), and further completed the total synthesis of palmatine.<smiles>C=Cc1cc(OC)c(OC)cc1-c1cc2ccc(OC)c(OC)c2cn1</smiles>

Scheme 2 Retrosynthetic analysis of palmatine. 
a) $\mathrm{C}-\mathrm{H}$ vinylation of 2-arylpyridine<smiles>C=COC(=O)OC=CC(=O)OCCCC</smiles>

b) this work<smiles>BrC=C[I-]c1[R]cccc1-c1ccccn1</smiles><smiles>[R]c1ccc(-c2ccccn2)c(C=C)c1</smiles><smiles>C=Cc1cc(OC)c(OC)cc1-c1cc2ccc(OC)c(OC)c2cn1</smiles>

Scheme 3 Direct $\mathrm{C}-\mathrm{H}$ vinylation.

\section{Results and Discussion}

We started the vinylation reaction using 2-phenylpyridine (1a) and potassium vinyltrifluoroborate (2a) as the model substrates. The reaction using $\left[\mathrm{RhCp}^{*} \mathrm{Cl}_{2}\right]_{2}(2 \mathrm{~mol} \%)$ as a catalyst and $\mathrm{AgOAC}$ ( 1.5 equiv.) as an additive in $\mathrm{MeOH} / \mathrm{TFE}(1: 1)$ at $40^{\circ} \mathrm{C}$ for 8 hours under air furnished the corresponding products $3 \mathbf{a}$ and $\mathbf{3} \mathbf{a}^{\prime}$ in $78 \%$ (entry 1, - Table $\mathbf{1}$ ), while the use of other cationic Rh sources resulted in a large decrease in yield (entries 2-3, - Table 1). Almost no reaction occurred when switching to other catalysts, including Ru, Ir, and Co (entries 4-8, - Table 1 ), proving that catalyst $\mathrm{Rh}$ is curial for this transformation. Then a variety of solvents including DCE (1,2-dichloroethane), HFIP (hexafluoroisopropanol)/EtOH, DCM, HFIP, EtOH, and PEG-400 were tested, and we were surprised to find that EtOH gave the best result and afforded 3a and 3a' in 83\% yield in the presence of $\left[\mathrm{RhCp}^{*} \mathrm{Cl}_{2}\right]_{2}$ ( $2 \mathrm{~mol} \%$ ) and $\mathrm{AgOAc}$ (1.5 equiv.) (entries 9-14, - Table 1). Further screening of oxidants revealed that $\mathrm{Cu}$ $(\mathrm{OAc})_{2}, \mathrm{AgF}$, and $\mathrm{CuF}_{2}$ were inferior to $\mathrm{AgOAc}$ (entries 13, 15-17, - Table 1). Gratifyingly, decreasing reaction temperature to $30^{\circ} \mathrm{C}$ also afforded the desired product in high yield ( $82 \%$, entry $18,-$ Table 1 ). To our satisfaction, switching the amount of $\mathbf{2 a}$ to 1.1 equivalents did not lower the yields of $\mathbf{3 a}$ and 3a'. And more importantly, the ratio of the corresponding mono- and divinylated products $\mathbf{3 a}$ and $\mathbf{3} \mathbf{a}^{\prime}$ was significantly improved (entry 19, - Table 1). Thus, the optimal reaction conditions were finally determined as follows: $\mathbf{1 a}(0.2 \mathrm{mmol})$, 2a $(0.22 \mathrm{mmol}),\left[\mathrm{RhCp}^{*} \mathrm{Cl}_{2}\right]_{2}$ (2 mol\%), AgOAc (1.5 equiv.), in $\mathrm{EtOH}$ at $30^{\circ} \mathrm{C}$ for 8 hours under air.

Having the optimized conditions in hand, we then explored the practicality of this novel method by applying the procedure to the vinylation of a wide range of arenes (-Fig. 1 ).

Generally, 2-phenylpyridines with substituents at different positions of the aromatic ring all reacted smoothly with $\mathbf{2 a}$, giving the corresponding products in moderate to good yields. For example, 2-phenylpyridines containing methyl substituents at the ortho-, meta- and para-positions of the benzene ring afforded the desired products $\mathbf{3 b}$, $\mathbf{3 d}$, and $\mathbf{3 h}$ and $\mathbf{3} \mathbf{h}^{\prime}$ in $\mathbf{7 5}$, 90 , and $55 \%$ yields, respectively. Both electron-donating and withdrawing groups were tolerated, as demonstrated by the isolation of $66 \%$ of $3 \mathbf{e}$ and $81 \%$ of $\mathbf{3 g}$. Similarly, the reaction of chloro-substituted 2-phenylpyridine provided the corresponding product $\mathbf{3 f}$ in a lower yield. To our satisfaction, this method is compatible well with 3-phenylisoquinoline and gave the corresponding products $\mathbf{3} \mathbf{i}$ and $\mathbf{3} \mathbf{i}^{\prime}$ in moderate yield. When the aromatic ring without substitution at the ortho- or meta-positions was used, divinylated products are obtained, such as $\mathbf{3} \mathbf{h}^{\prime}$ and $\mathbf{3} \mathbf{i}$. On the basis of these results, we decided to verify the synthetic applicability of the developed protocol for the synthesis of the natural isoquinoline alkaloid palmatine. 
Table 1 Optimization of the reaction conditions ${ }^{a}$

\begin{tabular}{|c|c|c|c|c|c|}
\hline \multicolumn{6}{|l|}{ FO1 } \\
\hline \multirow[t]{2}{*}{ Entry } & \multirow[t]{2}{*}{ Catalyst } & \multirow[t]{2}{*}{ Oxidant } & \multirow[t]{2}{*}{ Solvents } & \multicolumn{2}{|c|}{ Yield $(\%)^{b}$} \\
\hline & & & & $3 a+3 a^{\prime}$ & $3 a: 3 a^{\prime c}$ \\
\hline 1 & {$\left[\mathrm{RhCp} * \mathrm{Cl}_{2}\right]_{2}$} & $\mathrm{AgOAC}$ & $\mathrm{MeOH} / \mathrm{TFE}$ & 78 & $1: 0.45$ \\
\hline 2 & {$\left[\mathrm{Rh}(\mathrm{OAc})_{2}\right]_{2}$} & $\mathrm{AgOAC}$ & $\mathrm{MeOH} / \mathrm{TFE}$ & N.R. ${ }^{d}$ & - \\
\hline 3 & {$\left[\mathrm{Cp} * \mathrm{Rh}(\mathrm{MeCN})_{3}\right]\left(\mathrm{SbF}_{6}\right)_{2}$} & $\mathrm{AgOAC}$ & $\mathrm{MeOH} / \mathrm{TFE}$ & 45 & $1: 0.43$ \\
\hline 4 & {$\left[\mathrm{RuCl}_{2}(p \text {-cymene })\right]_{2}$} & $\mathrm{AgOAC}$ & $\mathrm{MeOH} / \mathrm{TFE}$ & 13 & 1: 0.45 \\
\hline 5 & {$\left[\mathrm{IrCp} * \mathrm{Cl}_{2}\right]_{2}$} & $\mathrm{AgOAC}$ & $\mathrm{MeOH} / \mathrm{TFE}$ & N.R & - \\
\hline 6 & $\mathrm{Co}(\mathrm{acac})_{3}$ & $\mathrm{AgOAC}$ & $\mathrm{MeOH} / \mathrm{TFE}$ & N.R & - \\
\hline 7 & $\mathrm{Co}(\text { acac })_{2}$ & $\mathrm{AgOAC}$ & $\mathrm{MeOH} / \mathrm{TFE}$ & N.R & - \\
\hline 8 & {$\left[\mathrm{Cp}{ }^{*} \mathrm{Co}(\mathrm{CO}) \mathrm{I}_{2}\right]$} & $\mathrm{AgOAc}$ & $\mathrm{MeOH} / \mathrm{TFE}$ & N.R & - \\
\hline 9 & {$\left[\mathrm{RhCp}^{*} \mathrm{Cl}_{2}\right]_{2}$} & $\mathrm{AgOAC}$ & DCE & 50 & $1: 0.5$ \\
\hline 10 & {$\left[\mathrm{RhCp}^{*} \mathrm{Cl}_{2}\right]_{2}$} & $\mathrm{AgOAC}$ & HFIP/EtOH & 73 & 1:0.45 \\
\hline 11 & {$\left[\mathrm{RhCp}^{*} \mathrm{Cl}_{2}\right]_{2}$} & $\mathrm{AgOAC}$ & DCM & 47 & $1: 0.45$ \\
\hline 12 & {$\left[\mathrm{RhCp}^{*} \mathrm{Cl}_{2}\right]_{2}$} & $\mathrm{AgOAC}$ & HFIP & 10 & $1: 0.47$ \\
\hline 13 & {$\left[\mathrm{RhCp}^{*} \mathrm{Cl}_{2}\right]_{2}$} & $\mathrm{AgOAc}$ & $\mathrm{EtOH}$ & 83 & $1: 0.45$ \\
\hline 14 & {$\left[\mathrm{RhCp}^{*} \mathrm{Cl}_{2}\right]_{2}$} & $\mathrm{AgOAC}$ & PEG-400 & 43 & $1: 0.5$ \\
\hline 15 & {$\left[\mathrm{RhCp}^{*} \mathrm{Cl}_{2}\right]_{2}$} & $\mathrm{Cu}(\mathrm{OAc})_{2}$ & $\mathrm{EtOH}$ & 79 & $1: 0.45$ \\
\hline 16 & {$\left[\mathrm{RhCP}^{*} \mathrm{Cl}_{2}\right]_{2}$} & $\mathrm{AgF}$ & $\mathrm{EtOH}$ & 70 & 1:0.45 \\
\hline 17 & {$\left[\mathrm{RhCP}^{*} \mathrm{Cl}_{2}\right]_{2}$} & $\mathrm{CuF}_{2}$ & $\mathrm{EtOH}$ & 64 & $1: 0.47$ \\
\hline $18^{\mathrm{e}}$ & {$\left[\mathrm{RhCP}^{*} \mathrm{Cl}_{2}\right]_{2}$} & $\mathrm{AgOAC}$ & $\mathrm{EtOH}$ & 82 & 1:0.45 \\
\hline $19^{e, f}$ & {$\left[\mathrm{RhCp} * \mathrm{Cl}_{2}\right]_{2}$} & AgOAc & EtOH & 82 & $1: 0.08$ \\
\hline
\end{tabular}

${ }^{\mathrm{a}}$ Reaction conditions: $1 \mathrm{a}(0.2 \mathrm{mmol}), 2 \mathrm{a}(0.3 \mathrm{mmol})$, catalyst $(2 \mathrm{~mol} \%)$, oxidant $(1.5$ eq. $)$, solvents $(1 \mathrm{~mL}), 40^{\circ} \mathrm{C}$ for 8 hours under air.

bIsolated yields by chromatography on silica gel.

'The ratio of $3 a$ and $3 a$ ' was determined by ${ }^{1} \mathrm{H}$ NMR spectroscopy.

${ }^{\mathrm{d}}$ No reaction.

e $30^{\circ} \mathrm{C}$.

f2a $(0.22 \mathrm{mmol})$.<smiles>C=Cc1cccc(C)c1-c1ccccn1</smiles>

3b $75 \%$<smiles>C=Cc1ccc(C(=O)OC)cc1-c1ccccn1</smiles>

$3 g$ 81\%<smiles>C=Cc1cccc(OC)c1-c1ccccn1</smiles>

3c $78 \%$<smiles>C=Cc1cc(C)ccc1-c1ccccn1</smiles><smiles>C/C=C\CC=[Te]</smiles><smiles>C=Cc1cc(OC)c(I)cc1-c1ccccn1</smiles>

3e $66 \%$<smiles>C=Cc1ccc(Cl)cc1-c1ccccn1</smiles>

3f $48 \%$

Fig. 1 Substrate scope. Reaction conditions: 1 ( $0.2 \mathrm{mmol}), 2 \mathrm{a}(0.22 \mathrm{mmol}),\left[\mathrm{RhCp}{ }^{*} \mathrm{Cl}_{2}\right]_{2}(2 \mathrm{~mol} \%), \mathrm{AgOAc}(1.5 \mathrm{equiv}$ ), EtOH ( $1 \mathrm{~mL}), \mathrm{under}$ air, $30^{\circ} \mathrm{C}, 8$ hours, Isolated yields. ${ }^{a}$ Ratio of single to double $\mathrm{C}-\mathrm{H}$ activation products by ${ }^{1} \mathrm{H}$ NMR. 
<smiles>C=Cc1cc(OC)c(OC)cc1-c1cc2ccc(OC)c(OC)c2cn1</smiles>

\begin{tabular}{c} 
1) $\mathrm{B}_{2} \mathrm{Pin}_{2}$ \\
$\mathrm{Cu}_{2} \mathrm{O}, \mathrm{PPh}_{3}, \mathrm{~K}_{2} \mathrm{CO}_{3}, \mathrm{Ar}$ \\
$\mathrm{MeOH}, 30^{\circ} \mathrm{C}, 20 \mathrm{~h}$ \\
\hline $\begin{array}{c}\mathrm{H}_{2} \mathrm{O}_{2} / \mathrm{NaOH} \\
97 \%\end{array}$
\end{tabular}

$97 \%$<smiles>COc1cc(CCO)c(-c2cc3ccc(OC)c(OC)c3cn2)cc1OC</smiles>

D<smiles>COc1cc2c(cc1OC)-c1cc3ccc(OC)c(OC)c3c[n+]1CC2</smiles>

Scheme 4 Total synthesis of palmatine by $\mathrm{C}-\mathrm{H}$ activation.

As shown in Scheme 4, palmatine was successfully synthesized from commercially available materials in only four steps, and the crucial two-step $\mathrm{C}-\mathrm{H}$ activation reactions both were first reported by our group. First, intermediate B was obtained by Rh-catalyzed $\mathrm{C}-\mathrm{H}$ activation/cyclization of primary amine $\mathbf{A}$ with sulfoxonium ylide according to our recent work. ${ }^{15}$ Second, compound $\mathbf{B}$ reacted with potassium vinyltrifluoroborate under standard conditions, giving the key intermediate $\mathbf{C}(\mathbf{3 j})$ in $70 \%$ yield. Finally, compound $\mathbf{C}$ was easily converted into palmatine through hydroboration oxidation and cyclization reactions. ${ }^{25,26}$

\section{Conclusions}

In summary, we have developed a mild and efficient protocol by Rh-catalyzed direct $\mathrm{C}-\mathrm{H}$ ortho-vinylation of 2-arylpyridines using commercially available and air-stable potassium vinyltrifluoroborate as a vinyl source. The salient features of this protocol include using a low-toxicity solvent (EtOH) as reaction solution, mild reaction conditions, and moderate to excellent yields. More importantly, 3-arylisoquinolines, the skeleton of palmatine, were well tolerated in this process. Thus a short and efficient synthesis route of palmatine over four steps was developed with this methodology.

\section{Conflict of Interest}

The authors declare no conflicts of interest.

\section{Acknowledgments}

We are grateful for support from the National Natural Science Foundation of China (NSFC; grants 81373259 and 81573286).

\section{References}

1 Saha D, Mukhopadhyay C. Metal nanoparticles: an efficient tool for heterocycles synthesis and their functionalization via $\mathrm{CH}$ activation. Curr Organocatal 2019;6(02):79-91

2 Romero AH. Fused heteroaromatic rings via metal-mediated/catalyzed intramolecular $\mathrm{C}-\mathrm{H}$ activation: a comprehensive review. Top Curr Chem (Cham) 2019;377(04):21
3 Maraswami M, Loh TP. Transition-metal-catalyzed alkenyl $\mathrm{sp}^{2} \mathrm{C}$ H activation: a short account. Synthesis 2019;51(05):1049-1062

4 Abrams DJ, Provencher PA, Sorensen EJ. Recent applications of C-H functionalization in complex natural product synthesis. Chem Soc Rev 2018;47(23):8925-8967

5 Karimov RR, Hartwig JF. Transition-metal-catalyzed selective functionalization of $\mathrm{C}\left(\mathrm{sp}^{3}\right)-\mathrm{H}$ bonds in natural products. Angew Chem Int Ed Engl 2018;57(16):4234-4241

6 Yakura T, Nambu H. Recent topics in application of selective Rh (II)-catalyzed $\mathrm{CH}$ functionalization toward natural product synthesis. Tetrahedron Lett 2018;59(03):188-202

7 Potter TJ, Ellman JA. Total synthesis of (+)-pancratistatin by the $\mathrm{Rh}$ (III)-catalyzed addition of a densely functionalized benzamide to a sugar-derived nitroalkene. Org Lett 2017;19(11):2985-2988

8 Kinsinger T, Kazmaier U. C-H functionalization of $\mathrm{N}$-methylated amino acids and peptides as tool in natural product synthesis: synthesis of abyssenine A and mucronine E. Org Lett 2018;20(23): 7726-7730

9 Zhang Y, Yang Z, Guo L, et al. Total synthesis of the isoquinoline alkaloid decumbenine B via $\mathrm{Ru}(\mathrm{III})$-catalyzed $\mathrm{C}-\mathrm{H}$ activation. Org Chem Front 2018;5(10):1604-1607

10 Yuan Y, Peng W, Liu Y, Xu Z. Palmatine attenuates isoproterenolinduced pathological hypertrophy via selectively inhibiting HDAC2 in rats. Int J Immunopathol Pharmacol 2017;30(04):406-412

11 Tarabasz D, Kukula-Koch W. Palmatine: a review of pharmacological properties and pharmacokinetics. Phytother Res 2020;34(01):33-50

12 Dhingra D, Kumar V. Memory-enhancing activity of palmatine in mice using elevated plus maze and morris water maze. Adv Pharmacol Sci 2012;2012:357368

13 Li Z, Zhao S, Kong X. Research progress of palmatine and its analogues. Guangdong Huagong 2015;42(08):7-9

14 Bian X, He L, Yang G. Synthesis and antihyperglycemic evaluation of various protoberberine derivatives. Bioorg Med Chem Lett 2006;16(05):1380-1383

15 Guo L, Tang B, Nie R, et al. C-H alkenylation/cyclization and sulfamidation of 2-phenylisatogens using $\mathrm{N}$-oxide as a directing group. Chem Commun (Camb) 2019;55(71):10623-10626

16 Liu YZ, Hu Y, Lv GH, et al. Synthesis of 1,2-benzothiazines via C-H activation/cyclization in a recyclable, mild system. ACS Sustain Chem\& Eng 2019;7(15):13425-13429

17 Lai R, Wu X, Lv S, et al. Synthesis of indoles and quinazolines via additive-controlled selective $\mathrm{C}-\mathrm{H}$ activation/annulation of $\mathrm{N}$-arylamidines and sulfoxonium ylides. Chem Commun (Camb) 2019; 55(28):4039-4042

18 Zhang HL, Jing L, Zheng Y, et al. Rhodium-catalyzed ortho-cyanation of 2-aryl-1,2,3-triazole: an alternative approach to suvorexant. Eur J Inorg Chem 2018;2018(06):723-729 
19 Nie R, Lai R, Lv S, et al. Water-mediated C-H activation of arenes with secure carbene precursors: the reaction and its application. Chem Commun (Camb) 2019;55(76):11418-11421

20 Matsuura Y, Tamura M, Kochi T, Sato M, Chatani N, Kakiuchi F. The $\mathrm{Ru}(\operatorname{cod})(\cot )$-catalyzed alkenylation of aromatic C-H bonds with alkenyl acetates. J Am Chem Soc 2007;129(32):9858-9859

21 Otley KD, Ellman JA. An efficient method for the preparation of styrene derivatives via $\mathrm{Rh}(\mathrm{III})$-catalyzed direct $\mathrm{C}-\mathrm{H}$ vinylation. Org Lett 2015;17(05):1332-1335

22 Mei ST, Jiang K, Wang NJ, et al. Rhodium-catalyzed direct C-H vinylation of arenes to access styrenes with vinyl acetate as a vinyl source. Eur J Inorg Chem 2015;2015(28):6135-6140
$23 \mathrm{Xu}$ J, Chen C, Zhao H, et al. Rhodium(I)-catalysed decarbonylative direct $\mathrm{C}-\mathrm{H}$ vinylation and dienylation of arenes. Org Chem Front 2018;5(05):734-740

24 Zhou CN, Xie HH, Zheng ZA, et al. Synthesis of terminal vinylindoles via $\mathrm{Rh}^{\mathrm{III}}$-catalyzed direct $\mathrm{C}-\mathrm{H}$ alkenylation with potassium vinyltrifluoroborate. Chemistry 2018;24(21):5469-5473

25 Hong SB, Liu MY, Zhang W, et al. Copper-catalyzed hydroboration of arylalkenes at room temperature. Tetrahedron Lett 2015;56 (18):2297-2302

26 Zhang L, Zuo Z, Wan X, Huang Z. Cobalt-catalyzed enantioselective hydroboration of 1,1-disubstituted aryl alkenes. J Am Chem Soc 2014;136(44):15501-15504 